\title{
EVALUATION OF THE PROTECTIVE EFFECTS OF JOJOBA EXTRACT AGAINST FUMONISIN TOXICITY IN RATS
}

\author{
Mohamed Reda ${ }^{1}$, Hafiza A. Sharaf ${ }^{2}$, Elhady M. Gaber ${ }^{3}$, \\ El-Sayed M. Embaby ${ }^{4}$, Noura El-Katan ${ }^{5}$, Mosaad A. Abdel-Wahhab ${ }^{6}$ \\ ${ }^{1}$ Botany Dept, Faculty of Science, Benha University, Benha, Egypt, ${ }^{2}$ Pathology Dept., National \\ Research Center, Dokki, Cairo, Egypt, ${ }^{3}$ Nutrition Institute, Cairo, Egypt, ${ }^{4}$ Plant Pathology Dept, ., \\ National Research Center, Dokki, Cairo, Egypt, ${ }^{5}$ Agouza Hospital, Agouza, Giza, Egypt, ${ }^{6}$ Food \\ Toxicology \& Contaminants Dept., National Research Center, Dokki, Cairo, Egypt,
}

\begin{abstract}
Aim of the work: The current study was conducted to evaluate the protective effect of the ethanolic extract of jojoba in rats treated with fumonisin. Material and Method: Forty mature male SpragueDawley rats were divided into four groups included the control groups and the groups treated with fumonisin-contaminated cultural materials $(60 \mathrm{mg} / \mathrm{L})$, the group treated orally with jojoba extract $(5$ $\mathrm{mg} / \mathrm{kg} \mathrm{b.w)}$ and the group treated with fumonisin and the extract. Results: the results indicated that fumonisin induced a significant decrease in RBCs, HB, platelets, WBCs and triglycerides accompanied with a significant increase in all the other biochemical parameters tested. Moreover, animals treated with fumonisin alone showed severe pathological and histochemical changes in the liver tissues. Animals treated with jojoba extract alone were comparable to the controls regarding the haematological, the biochemical parameters, the histological structure and histochemical picture of the liver. In conclusion: The extract contracted the toxic effects of fumonisin and succeeded to normalize all the parameters tested and improve the histological and histochemical structure of the liver.
\end{abstract}

Key words: Fumonisin, jojoba, antioxidant, liver, toxicity

\section{INTRODUCTION}

(Simmondsia chinensis) is an arid perennial shrub indigenous to Arizona, California and Northwestern Mexico (Hogan, 1978). It is also grown in Australia (Davidson, 1983), Brazil, Argentina and some Middle East countries (Borlaug et al., 1985). As much as $97 \%$ of jojoba liquid wax (JLW) consists of a mixture of esters of long chain fatty alcohols and long chain fatty acids. More than $60 \%$ of this mixture of esters contains cis-11-eicosenoic (jojob-enoic) acid (C20) (Bouali et al.,

2008). JLW contains a natural antioxidant postulated to be an allylic derivative of hydroxytoluene (Kampf et al., 1986). A protein rich residue remains after oil extraction of jojoba seeds known as defatted jojoba meal. This meal contains $20-32 \%$ of protein, consisting mainly of albumins (79\%) and globulins (21\%) (Shrestha et al.,

2002). It also contains approximately $15 \%$ of a group of glucosides, known as simmondsins (Van Boven et al., 2000). Eight glucoside compounds (simmondsin and seven simmondsin derivatives) have been isolated and identified form jojoba seeds (Bouali et al., 2008).

Jojoba oil has good markets in the cosmetics and lubricant industries (Cokelaere et al., 1996), and recently, it has been reported that the jojoba seeds possess anti-inflammatory activity (Habashy et al., 2005). Moreover, JLW was 
used in folk remedies for renal colic, sunburn, chaffed skin, hair loss, headache, wounds and sore throat (Yaron, 1987).

Fumonisins are a group of fungal toxins that are commonly found on corn (Shephard et al., 1996) and other cereals grains used worldwide in animal feed and human foods (Visconti et al., 1991 and Pohland, 1996). Several studies have reported that $F$. moniliform and $\mathrm{FB}_{1}$ are hepatocarcinogenic in rats (Gelderblom et al., 1991; Abdel-Wahhab et al., 2002 and ElNekeety et al., 2007). Fumonisin $\mathrm{B}_{1}$ has been reported to

cause morphological and functional changes in chicken macrophages in vitro which indicate an immunosuppressing effect (Qureshi and Hagler, 1992). Fumonisin have been found to disrupt sphingolipids metabolism in hepatocytes from Sprague Dawley rats (Wang et al., 1991; Abdel-Wahhab et al., 2004; Riley and Voss, 2006), ducks (Tran et al., 2005), and mice (Voss et al., 2002). Due to its structural similarity with sphingosine (Bezuidenhout et al., 1988; Laurent et al., 1989 and Kim et al., 2006), $\mathrm{FB}_{1}$ interferes with ceramide synthase leading to intracellular accumulation of sphingoid bases which mediate several key biological processes such as cell proliferation, and DNA replication. $\mathrm{FB}_{1}$ inhibits biosynthesis of cellular macromolecules (Abado-Becognee et al., 1998; and He et al., 2006), and it induces lipid peroxidation in both primary rat hepatocytes (Abel and Gelderblom, 1998 and El-Nekeety et al., 2007) and C6 glioma cells (Mobio et al., 2000). The present study aimed to evaluate the antioxidant effects of the ethanolic extract of jojoba against fumonisin toxicity in rats.

MATERIAL AND METHODS Plant material:Jojoba (Simmondsia chinensis)

stems, leaves and seeds were obtained from Orman garden, Giza and were identified by the Department of Botany, Fac. Science, Cairo University.

Preparation of jojoba extract:The ethanolic extract $(95 \%)$ of the different organs of jojoba was prepared by macerating the powdered defatted jojopa seeds (100 g) and the aerial parts (stems and leaves) (100 g) in successive portions of ethanol $95 \%$ till exhaustion. The extract in each case was pooled and evaporated under reduced pressure to obtain a semisolid residue. A $20 \%(\mathrm{w} / \mathrm{v})$ solution of each extract in biodistilled water containing few drops of Tween 80 was prepared and used for treatment of animals.

FBs production: FBs were produced through the inculcation of PDA media by $F$. moniliforme isolated from fruits samples (banana) collected from local markets in Cairo as described by Voss et al. (1993). In brief, Fusarium isolates were suspended in sterile water and used to inoculate the liquid media $(500 \mathrm{~g})$ in $2-\mathrm{L}$ glass flask previously autoclaved at $121{ }^{\circ} \mathrm{C}$ for $1 \mathrm{~h}$ on each of 2 consecutive days. Cultures were incubated in the dark at $25{ }^{\circ} \mathrm{C}$ for 21 days. $\mathrm{FBs}$ in the culture media was measured by high performance liquid chromatography HPLC) according to Shephard et al. (1990). Briefly, FBs was extracted from a sample of the culture material with methanol-water $(3: 1 \mathrm{vol} / \mathrm{vol})$. The extract was purified on a strong anion-exchange cartridge, and an aliquot was derivatized with a reversed-phase column, monitored by fluorescence detection, and quantified by comparison of peak areas with those obtained with reference standards of $\mathrm{FB}_{1}, \mathrm{FB}_{2}$ and $\mathrm{FB}_{3}$. The FBs within the cultural material consisted of $70 \% \mathrm{FB}_{1}, 20 \% \mathrm{FB}_{2}$ and $10 \% \mathrm{FB}_{3}$ based on the total FBs in the cultural material. The cultural material was administrated orally to the experimental rats at dose of $1 \mathrm{ml} /$ rat (containing $60 \mathrm{mg} / \mathrm{L}$ total fumonisins).

Experimental animals: Three months old Sprague-Dawley male rats (100-120 g ) were purchased from the Animal House Colony, Giza, Egypt and were maintained on standard lab diet (protein: 160.4; fat: 36.3; fiber: $41 \mathrm{~g} / \mathrm{kg}$ and metabolizable energy $12.08 \mathrm{MJ}$ ) in artificial illuminated and temperature controlled room free from any other source of chemical contamination at the Nutrition Institute, Cairo, Egypt. After an acclimatization period of 1 week, the animals were divided into four groups (10 rats/group) and housed in filter-top polycarbonate cages. All animals were received humane care in 
compliance with the guidelines of the Animal Care and Use Committee of the Nutrition Institute, Cairo, Egypt.

Experimental design: Experimental groups of animals were maintained on the control diets for 3 weeks and were included the untreated control group; the group treated orally with $1 \mathrm{ml} \mathrm{FB}$ cultural material (60 mg FBs); the group treated orally with jojoba extract $(0.5 \mathrm{mg} / \mathrm{kg}$ b.w. in 0.5 $\mathrm{ml}$ distilled water) and the group treated orally with $\mathrm{FB}_{1}$ cultural material and jojoba extract at the same doses. Body weight was recorded daily allover the experimental period. At the end of the treatment period, two blood samples were collected from the retro-orbital venous plexus of all animals after fasting for $12 \mathrm{~h}$. The first blood sample from each animal within each experimental group was placed in plastic tubes containing EDTA and assayed on the same day for hematological parameters using sysmex S.F 3000 (USA). The following hematological parameters were determined: hemoglobin $(\mathrm{Hb})$, red blood cells counts (RBCs), white blood cell counts (WBCs) and platelets count. The second blood sample from each animal was left to clot and centrifuged at $5000 \mathrm{rpm}$ under cooling for $10 \mathrm{~min}$ to separate the serum for other biochemical analyses using Beckman cyncron cx5 (USA). The following biochemical parameters were determined: alanine aminotransferase (ALT), aspartate aminot-ransferase (AST), alkaline phosphatase (ALP), lactic dehydrogenase (LDH), createnine kinase (CK), triglycerides, cholesterol, urea, uric acid and createnine. After blood samples were collected, all animals were sacrificed and the liver of each animal was dissected and samples were excised and fixed in $10 \%$ neutral formalin, dehydrated in ascending grades of ethanol, cleaned in xylene and embedded in paraffin. Five $\mu \mathrm{m}$ thick sections were prepared and stained with hematoxylin and eosin (Hx\&E) according to Drury et al. (1976) for histological examination and other sections were stained with MercuricBromphenol blue stain for demonstration the total protein (Mazia et al., 1953) and Feulegn technique for demonstration of DNA (Bancroft and Stevens 1990). Three sections from each of the control and treated animals were microscopically examined. Moreover, sections stained for DNA by Feulgen reaction and total protein by Mercuric-Bromphenol blue stain were measured using a computerized image analyzer and Image Pro plus software.

Statistical analysis:All the obtained data for hematological and biochemical parameters as well as DNA and protein were statistically analyzed using the General Linear Models Procedure of the Statistical Analysis System (SAS, 1982) and student t-test. The significance of the differences among treatment groups was determined

Waller-Duncan k-ratio (Waller and Duncan, 1969). All statements of significance were based on probability of $\mathrm{P} \leq 0.05$.

\section{RESULTS}

The results of the current study revealed that animals treated with FBs alone showed a significant decrease in the body weight compared to the control group (Fig.

1). Animals treated with jojoba extract alone were comparable to the control group. However, the extract succeeded to restore the body weight towards the normal values of the control (Fig. 1). 


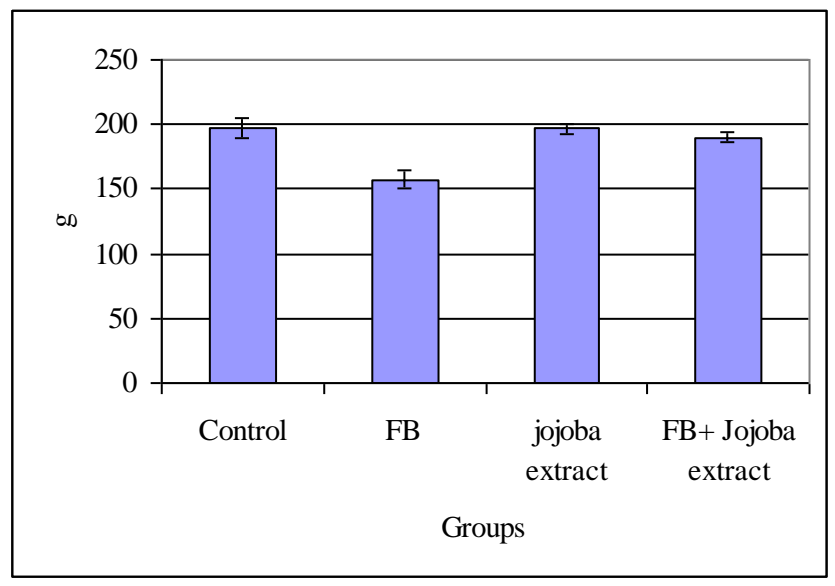

Fig. (1) Effect of Jojoba extract on the body weight in rats treated with FBs for 3 weeks

The results of the haematological study (Table 1) revealed that treatment with FB resulted in a significant decrease in count of RBCs, platelets, WBCs and $\mathrm{Hb}$ concentration. However, these parameters were comparable to the control group in the animals treated with the extract alone or in combination with FB. On the other hand, the biochemical results (Table 2) revealed that FB alone induced a significant increase in all biochemical parameters tested except cholesterol level which was found to decrease significantly.
The extract alone resulted in a significant decrease in ALT, LDH and CK, whereas; it did not affect significantly the other parameters. The administration of the extract to the animals treated with FB resulted in a significant improvement in all the biochemical parameters although most of them were still significantly differing than the control values. However, the combined treatment succeeded to restore ALP, triglycerides, cholesterol, urea and createnine nearly to the normal values of the control (Table 2). 
Table (1). Effect of jojoba extract on some hematological parameters in rats treated with FB for 4 weeks (means \pm SE)

\begin{tabular}{|c|c|c|c|c|}
\hline $\begin{array}{l}\text { Groups } \\
\text { Parameter }\end{array}$ & Control & FB & Jojoba extract & $\begin{array}{c}\text { Jojoba extract } \\
+ \text { FB }\end{array}$ \\
\hline $\begin{array}{c}\text { RBCs } \\
\left(\text { No X } 10^{6} / \mu 1\right)\end{array}$ & $\begin{array}{c}6.33 \\
\pm 0.14^{\mathrm{a}}\end{array}$ & $\begin{array}{c}4.23 \\
\pm 0.33^{\mathrm{b}}\end{array}$ & $\begin{array}{c}5.75 \\
\pm 0.17^{\mathrm{a}}\end{array}$ & $\begin{array}{c}6.15 \\
\pm 0.15^{\mathrm{a}}\end{array}$ \\
\hline $\begin{array}{l}\mathrm{Hb} \\
(\mathrm{g} / \mathrm{dl})\end{array}$ & $\begin{array}{r}12.25 \\
\pm 0.23^{\mathrm{a}}\end{array}$ & $\begin{array}{c}7.83 \\
\pm 0.61^{\mathrm{b}}\end{array}$ & $\begin{array}{c}12.22 \\
\pm 0.29^{\mathrm{a}}\end{array}$ & $\begin{array}{c}12.53 \\
\pm 0.41^{\mathrm{a}}\end{array}$ \\
\hline $\begin{array}{l}\text { Platelets } \\
\left(\text { No X } 10^{3} / \mu 1\right)\end{array}$ & $\begin{array}{l}770.83 \\
\pm 57.3^{\mathrm{a}}\end{array}$ & $\begin{array}{r}318.17 \\
\pm 18.75^{\mathrm{b}}\end{array}$ & $\begin{array}{r}784.83 \\
\pm 54.76^{\mathrm{a}}\end{array}$ & $\begin{aligned} & 771.5 \\
\pm & 32.37^{\mathrm{a}}\end{aligned}$ \\
\hline $\begin{array}{c}\text { WBCs } \\
\left(\text { No X } 10^{3} / \mu 1\right)\end{array}$ & $\begin{array}{c}20.15 \\
\pm 2.01^{\mathrm{a}}\end{array}$ & $\begin{array}{c}11.98 \\
\pm 0.68^{\mathrm{b}}\end{array}$ & $\begin{array}{c}20.74 \\
\pm 0.79^{\mathrm{a}}\end{array}$ & $\begin{array}{c}19.41 \\
\pm 0.83^{\mathrm{a}}\end{array}$ \\
\hline
\end{tabular}

Within each raw, means superscript with different letters are significantly different $(\mathrm{P} \leq 0.05)$

Table (2). Effect of jojoba extract on biochemical parameters in rats treated with FB for 3 weeks (means $\pm \mathrm{SE}$ )

\begin{tabular}{|c|c|c|c|c|}
\hline $\begin{array}{l}\text { Groups } \\
\text { Parameter }\end{array}$ & Control & FB & Jojoba extract & $\begin{array}{c}\text { Jojoba extract } \\
+ \text { FB }\end{array}$ \\
\hline $\begin{array}{l}\text { ALT } \\
\text { (IU/L) }\end{array}$ & $\begin{array}{c}88.33 \\
\pm 2.99^{\mathrm{a}}\end{array}$ & $\begin{array}{r}157.0 \\
\pm 20.49^{\mathrm{b}}\end{array}$ & $\begin{array}{c}68.33 \\
\pm 1.94^{\mathrm{c}}\end{array}$ & $\begin{array}{l}107.33 \\
\pm 3.39^{\mathrm{d}}\end{array}$ \\
\hline $\begin{array}{l}\text { AST } \\
\text { (IU/L) }\end{array}$ & $\begin{array}{r}182.67 \\
\pm 4.87^{\mathrm{a}}\end{array}$ & $\begin{array}{r}410.5 \\
\pm 46.01^{\mathrm{b}}\end{array}$ & $\begin{array}{r}178.83 \\
\pm 9.46^{\mathrm{a}}\end{array}$ & $\begin{array}{l}221.67 \\
\pm 5.04^{\mathrm{c}}\end{array}$ \\
\hline $\begin{array}{l}\text { ALP } \\
\text { (IU/L) }\end{array}$ & $\begin{array}{c}300.17 \\
\pm 15.72^{\mathrm{a}}\end{array}$ & $\begin{array}{c}486 \\
\pm 14.02^{\mathrm{b}}\end{array}$ & $\begin{array}{r}295.67 \\
\pm 13.07^{\mathrm{a}}\end{array}$ & $\begin{array}{c}295.17 \\
\pm 17.13^{\mathrm{a}}\end{array}$ \\
\hline$\underset{(\mathrm{mg} / \mathrm{dl})}{\text { Triglycerides }}$ & $\begin{array}{c}66.0 \\
\pm 0.37^{\mathrm{a}}\end{array}$ & $\begin{array}{l}128.33 \\
\pm 1.36^{\mathrm{b}}\end{array}$ & $\begin{array}{c}54.5 \\
\pm 2.28^{\mathrm{a}}\end{array}$ & $\begin{array}{c}64.5 \\
\pm 3.38^{\mathrm{a}}\end{array}$ \\
\hline $\begin{array}{c}\text { Cholesterol } \\
\text { (mg/dl) }\end{array}$ & $\begin{array}{c}70.5 \\
\pm 1.18^{\mathrm{a}}\end{array}$ & $\begin{array}{c}47.0 \\
\pm 3.48^{\mathrm{b}}\end{array}$ & $\begin{array}{c}63.5 \\
\pm 4.09^{\mathrm{a}}\end{array}$ & $\begin{array}{c}75.64 \\
\pm 4.67^{\mathrm{a}}\end{array}$ \\
\hline $\begin{array}{c}\text { LDH } \\
(\mathrm{U} / \mathrm{L})\end{array}$ & $\begin{array}{l}4038.67 \\
\pm 251.84\end{array}$ & $\begin{array}{r}6010.33 \\
\pm 476.92\end{array}$ & $\begin{array}{c}3491.0 \\
\pm 228.13\end{array}$ & $\begin{array}{c}3783.5 \\
\pm 182.18\end{array}$ \\
\hline $\begin{array}{c}\mathrm{CK} \\
(\mathrm{mg} / \mathrm{dl})\end{array}$ & $\begin{array}{r}19731.67 \\
\pm 666.74^{\mathrm{a}} \\
\end{array}$ & $\begin{array}{c}32775.0 \\
\pm 814.71^{\mathrm{b}}\end{array}$ & $\begin{array}{r}17365.0 \\
\pm 353.94^{\mathrm{c}} \\
\end{array}$ & $\begin{array}{r}17782.62 \\
\pm 367.66^{\mathrm{d}} \\
\end{array}$ \\
\hline $\begin{array}{l}\text { Urea } \\
(\mathrm{mg} / \mathrm{dl})\end{array}$ & $\begin{array}{c}43.83 \\
\pm 2.01^{\mathrm{a}}\end{array}$ & $\begin{array}{c}74.17 \\
\pm 1.94^{\mathrm{b}}\end{array}$ & $\begin{array}{c}42.83 \\
\pm 1.38^{\mathrm{a}}\end{array}$ & $\begin{array}{c}43.33 \\
\pm 0.99^{\mathrm{a}}\end{array}$ \\
\hline$\underset{(\mathrm{mg} / \mathrm{dl})}{\text { Createnine }}$ & $\begin{array}{c}0.52 \\
\pm 0.03^{\mathrm{a}}\end{array}$ & $\begin{array}{c}0.94 \\
\pm 0.04^{\mathrm{b}}\end{array}$ & $\begin{array}{c}0.48 \\
\pm 0.05^{\mathrm{a}}\end{array}$ & $\begin{array}{c}0.57 \\
\pm 0.05^{\mathrm{a}}\end{array}$ \\
\hline $\begin{array}{c}\text { Uric acid } \\
(\mathrm{mg} / \mathrm{dl})\end{array}$ & $\begin{array}{c}2.93 \\
\pm 0.21^{\mathrm{a}}\end{array}$ & $\begin{array}{c}49.7 \\
\pm 0.18^{\mathrm{b}}\end{array}$ & $\begin{array}{c}3.0 \\
\pm 0.47^{\mathrm{a}} \\
\end{array}$ & $\begin{array}{c}3.45 \\
\pm 0.2^{\mathrm{a}}\end{array}$ \\
\hline
\end{tabular}

Within each raw, means superscript with different letters are significantly different $(\mathrm{P} \leq 0.05)$ 
The histological examination of the control liver sections revealed normal histological structure of liver lobule and hepatocytes which are forming cords radiating from the central vein (Fig 2-a). Whereas, the liver of rats treated with fumonisin alone showed marked congestion and dilatation of the portal tract, necrosis and moderate proliferation of the bile duct epithelial cells (Fig. 2-b). The hepatocytes showed hepatocytes vacuolar degeneration and periportal necrosis (Fig 2-c). The microscopic examination of the liver in the fumonisin group also revealed dilatation in sinusiod. The nuclei are pleomorphism and others showed degrees of degeneration in the form of pyknosis, karyolysis, while some of the cells nuclei appeared completely absent (Fig. 2d). The histological examination of the liver in the animals treated with jojoba extract alone showed almost normal hepatocytes arc-hitecture, slight dilatation of blood sinusoid infiltrated by few inflammatory cells, increase in kupffer cells. Moreover, some fields showed vesicular binucleated hepatocytes (Fig. 3). The liver sections in the animals treated with fumonisin plus Jojoba extract showed marked improvement of hepatocytes architecture. The hepatocytes nuclei were vesicular and binucleated and increased in kupffer cells were also seen. Meanwhile, some dilatation and congestion of blood sinusoid were still present (Fig. 4).

DNA was histochemically demonstrated using Feulgen reaction technique (Fig. 5). The mean value per nucleus was measured by image analyzer and the results were expressed as optical density values (Fig. 6). The mean value for nuclear DNA content of hepatocytes nuclei of fumonisin-treated group $(0.18 \pm 0.001)$ was significantly decrease compared to the control group $(0.23 \pm 0.003)$. The mean DNA contents of jojoba extract alone $(0.25 \pm 0.002)$ or plus fumonisin-treated $(0.25 \pm 0.002)$ groups showed significant improvement compared to the control. The total protein content was histochemical demonstrated by Mercuric-Bromphenol blue stain (Fig 7, 8). The liver of rats treated with fumonisin only (Fig. 8-b) exhibited significant decrease in protein content in cytoplasm of hepatocytes $(0.173 \pm 0.001)$ as compared to control $(0.199 \pm 0.002)$ (Fig. 8-a). While, a significant increase in protein content was found in animals treated with extract only $(0.222 \pm$ 0.001) (Fig. 8-c) comparing to control or fumonisin groups. A significant decrease in protein content in rats treated with fumonisin plus Jojoba extract $(0.187 \pm 0.001)$ (Fig. 8-d) compared to the control or extract alone-treated group. Although it exhibited a significant increase compared to fumonisins alone-treated group $(0.173 \pm 0.001)$. 


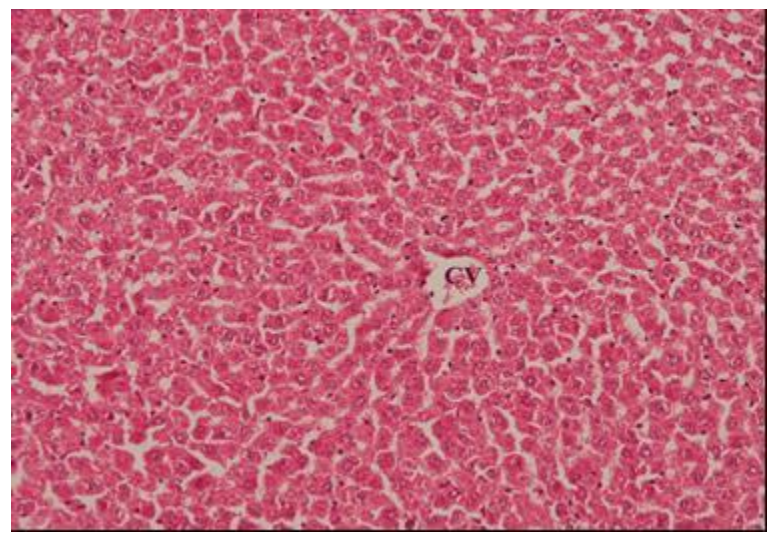

Fig. (2a). Liver sections of control animals showing the normal histological structure of liver lobule and hepatocytes which are forming cords radiating from the central vein (cv).

(H\&E X 200)

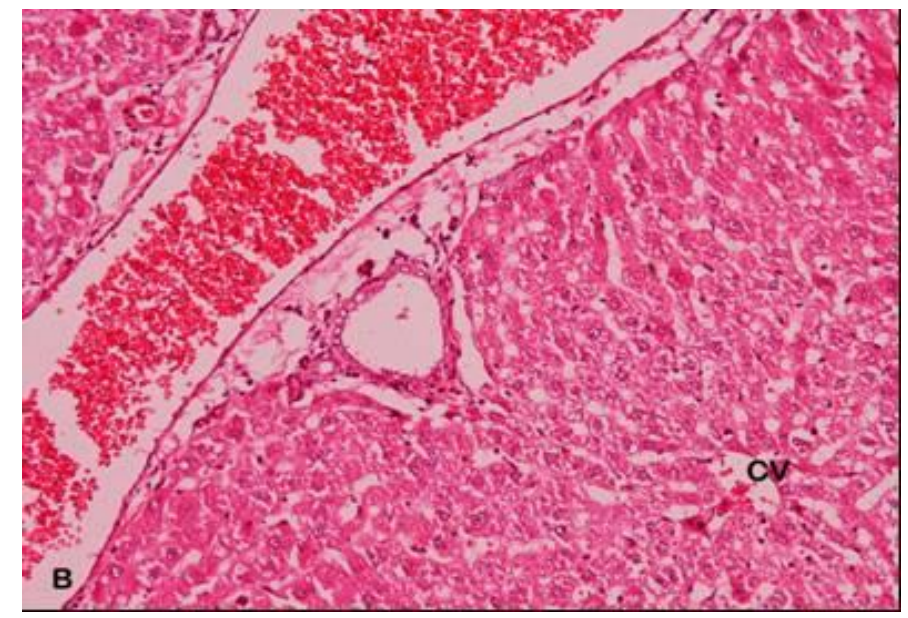

Fig. (2b). Liver sections of rat treated with fumonisin alone showing dilated and congested hepatic portal vessel, moderate proliferation of bile duct epithelial cells. 


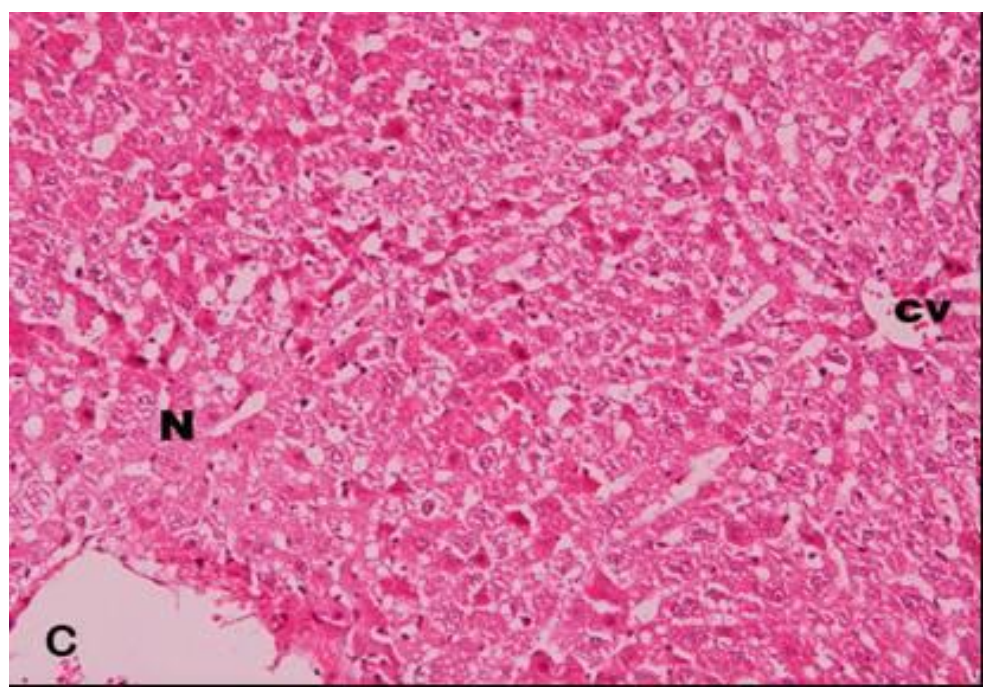

Fig. (2c). Liver sections of rat treated with fumonisin alone showing hepatocytes vacuolar degeneration and periportal necrosis $(\mathrm{N})$.

$(\mathrm{Hx} \& \mathrm{E}$ x200),

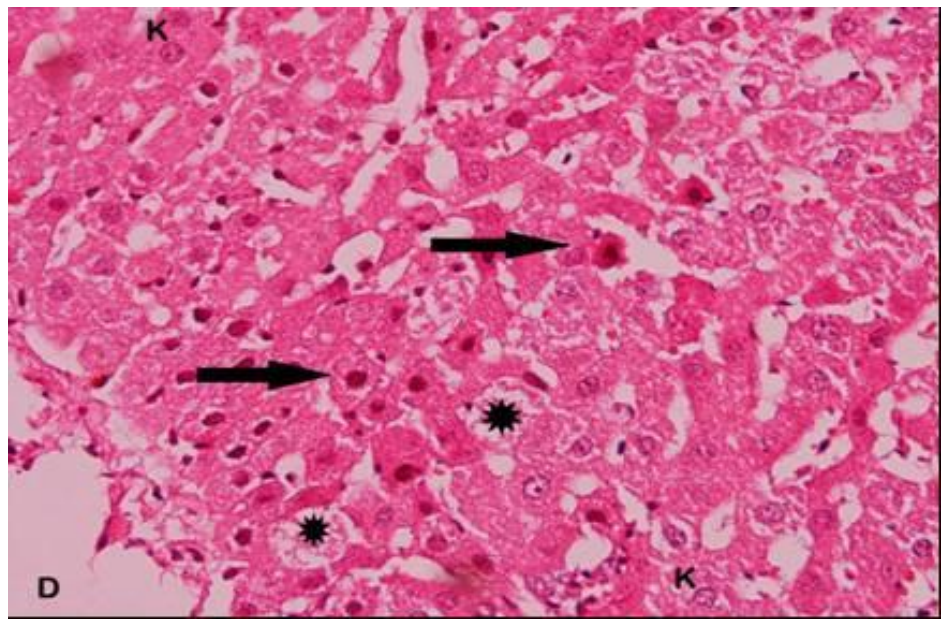

Fig. (2d). High magnification of previous figure showing moderate dilatation in sinusoid, necrosis, hepatocytes vacuolar degeneration, some of the nuclei showing degrees of degeneration in the form of pyknosis, (arrow) karyolysis (K) while some cells nuclei appeared completely absent (*). (H\&E X 400) 


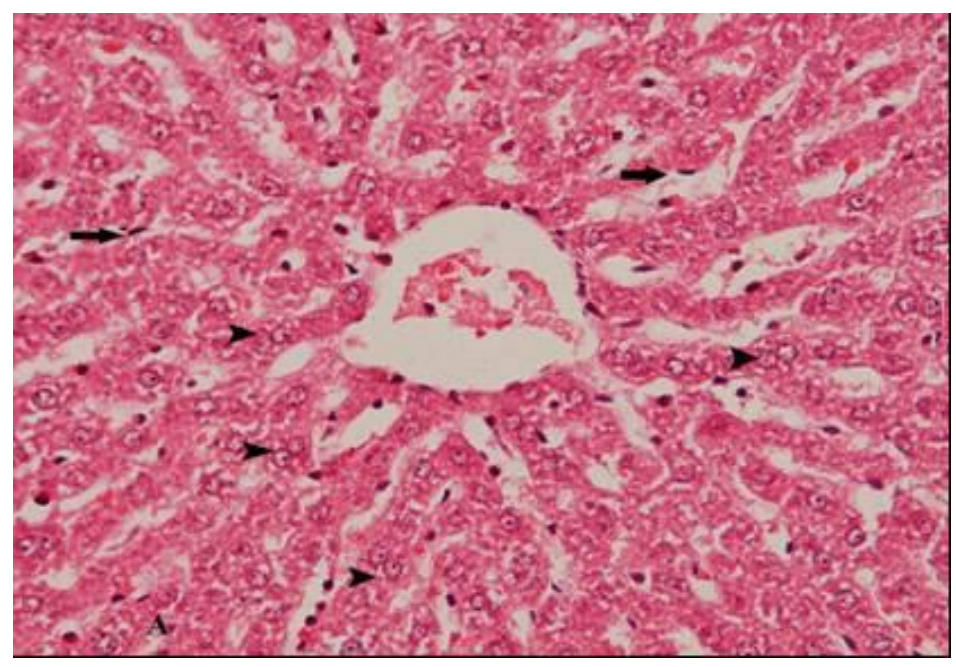

Fig. (3): liver sections of rat treated with jojoba extract alone showing almost normal architecture of hepatocytes, slight dilatation of blood sinusoid infiltrated by inflammatory cells, increase in kupffer cells (arrows) and vesicular binucleated hepatocytes (arrow head).

(Hx \&E X 400)

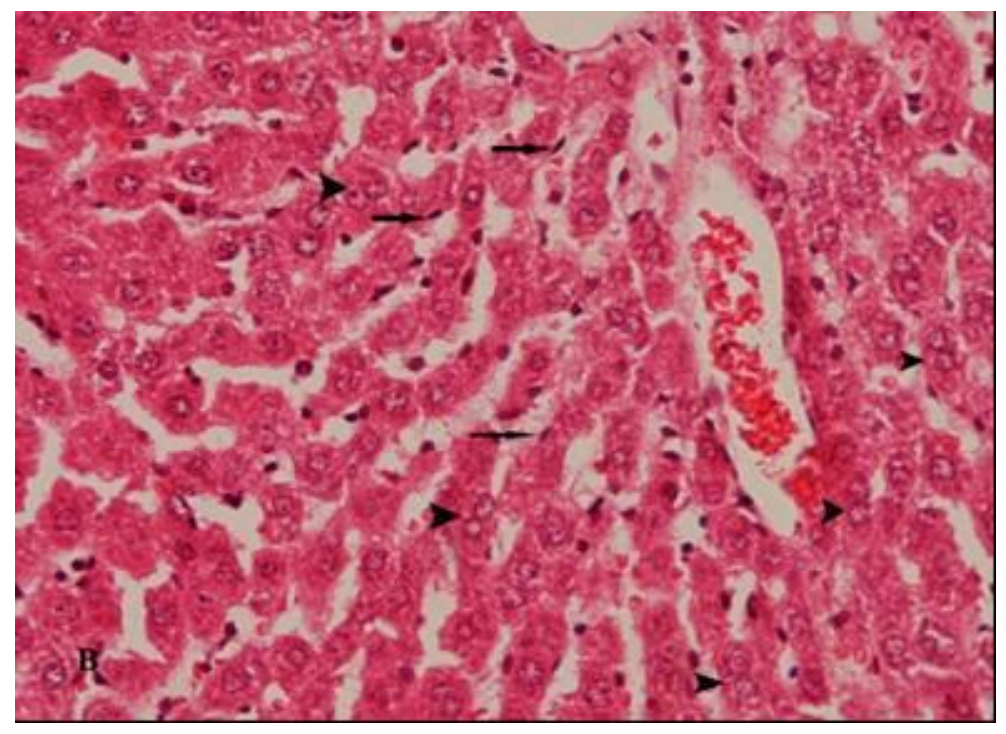

Fig. (4): liver sections of rat treated with fumonisin plus Jojoba extract showing marked improvement of hepatocytes architecture, hepatocytes nuclei are vesicular and binucleated (arrow head), increase in kupffer cells (arrow). Notice: some dilatation and congestion of blood sinusoid still present.

(H \& E X 400). 

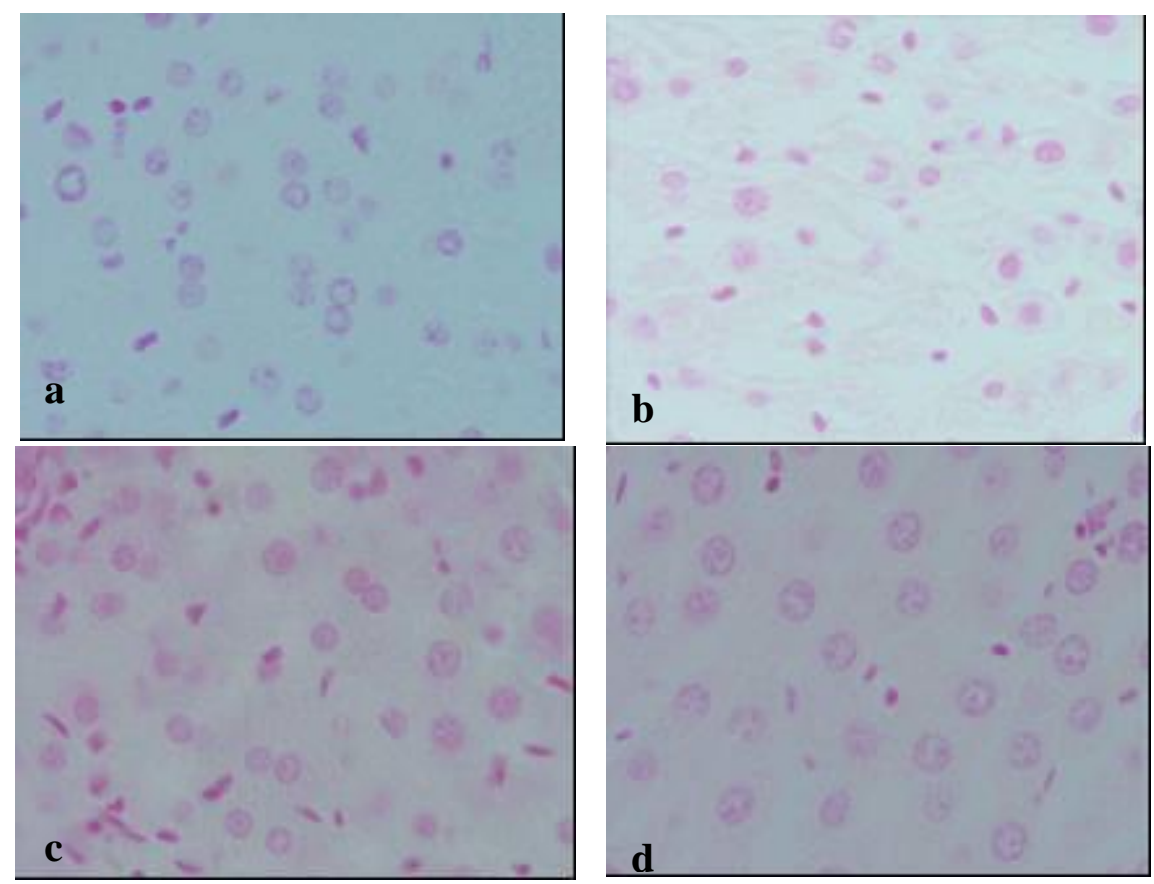

Fig. (5): liver sections of rat showing DNA content (a): control, (b): fumonisin alone treated animals showing a decrease in DNA content, (c): jojoba extract alone-treated animals showing slight increase in DNA content compared to the control and (d) fumonisin plus Jojoba extracttreated animals showing a highly increase in DNA content compared to fumonisin-treated group.

(Feulgen reaction $\mathrm{X} 400$ )

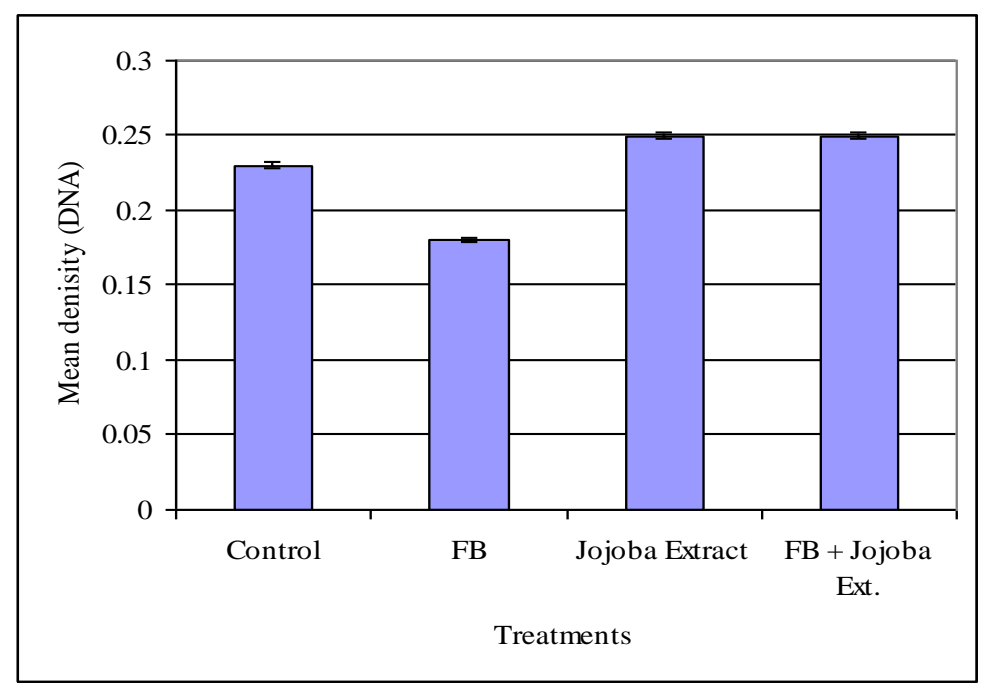

Fig. (6): The mean optical density values of nuclear DNA in hepatocytes nuclei of different groups 


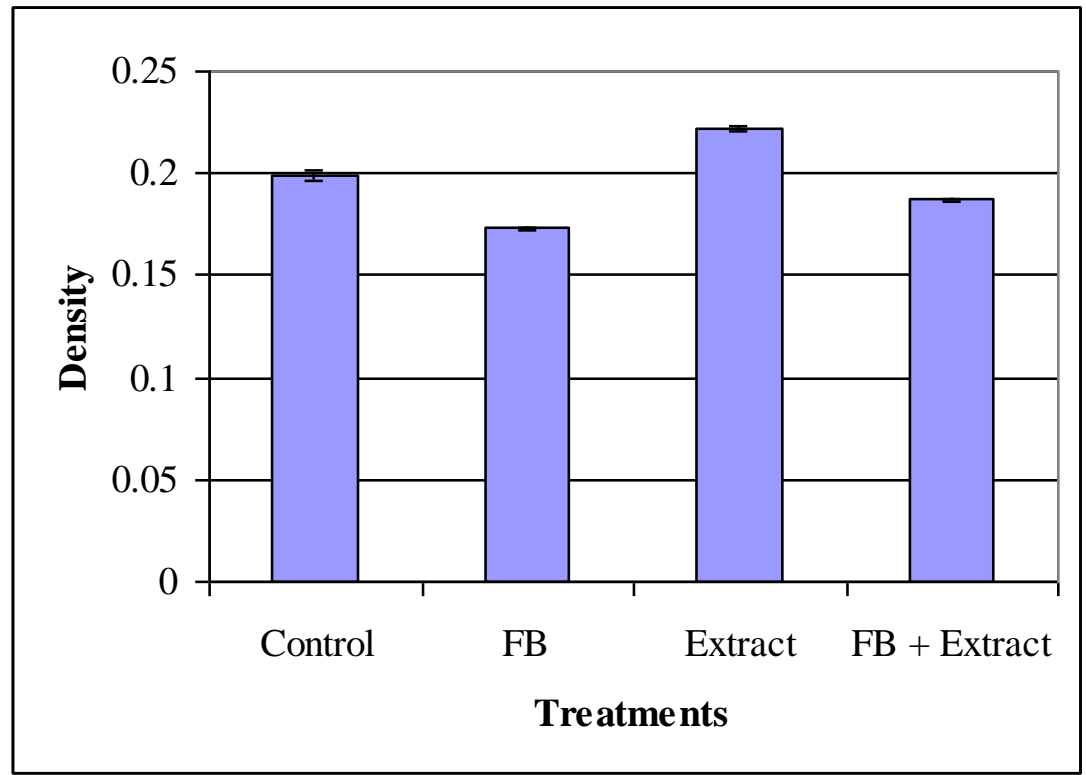

Fig. (7): The mean optical density values of protein content of hepatocytes of different groups
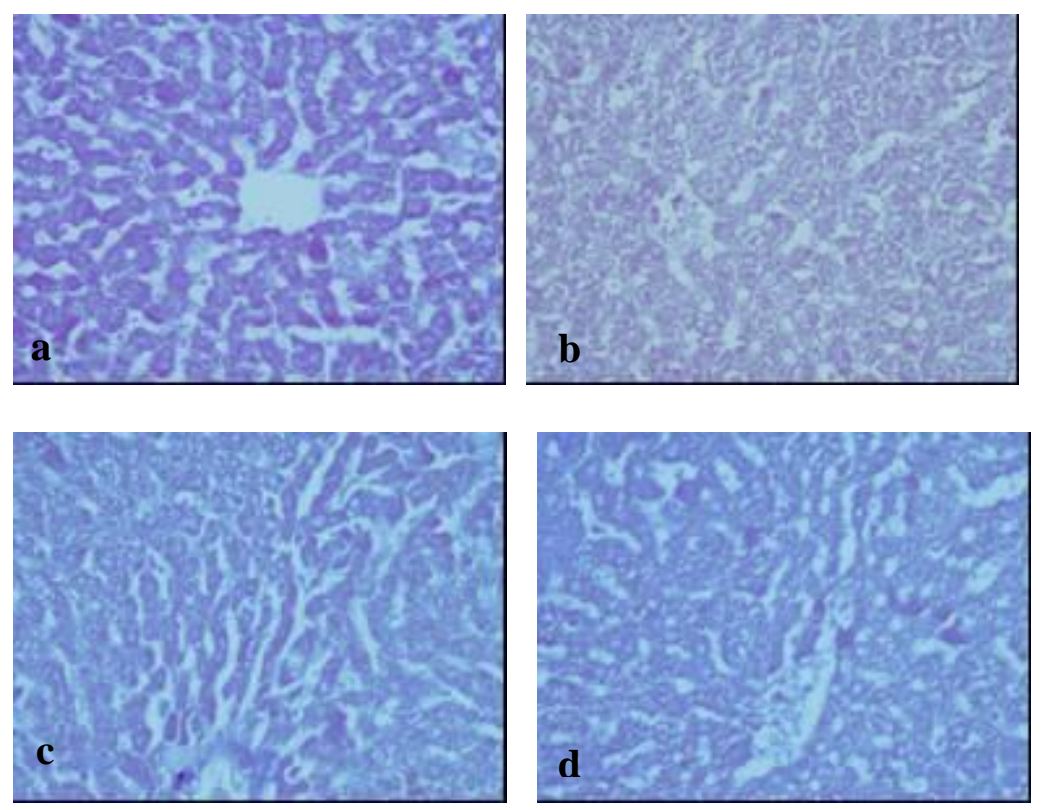

Fig. (8): liver sections of rat showing protein content in cytoplasm of hepatocytes (a): control showing normal distribution of protein, (b): fumonisin alone-treated animals, showing decrease in protein content, (c): jojoba extract alone-treated animals showing moderate increase in protein content compared to control and (d) fumonisin plus Jojoba extract-treated animals showing slight increase in protein content compared to toxin group. (Bromophenol blue stain X 400). 


\section{DISCUSSION}

In the current study, we evaluated the ability of ethanolic extract of jojoba to protect the laboratory animals from the toxic effects of FB. The tested animals were given an extreme FB challenge to ensure induction of severe response. The selective doses of FB and extract were literature based (Abdel-Wahhab et al., 2004 and Habashy et al., 2005) respectively. The decrease in body weight gain reported in the current

study indicated the presence of adverse effects and toxicity in rats due to receiving FB. This decrease may indicate protein catabolism, thereby contributing to the observed kidney injury (Abdel-Wahhab et al., 2002, 2004; Tessari et al., 2006 and El-Nekeety et al., 2007). Similar decrease in body weight loss had been reported in rats (Abdel-Wahhab et al., 2002 and El-Nekeety et al., 2007), swine (Haschek et al., 1992) horses (Ross et al., 1993), broiler (Brown et al., 1992) and turkey poults (Weibling et al., 1993a) fed fumonisin.

Previously, Abdel-Wahhab et al. (2004) and ElNekeety et al. (2007) stated that administration of FB to rats enhanced lipid peroxidation which is presumably results of free-radical-mediated toxicity. Stockmann-Juvala et al. (2004) found that FB evoke oxidative stress, which may contribute at least in part to FB toxicity and carcinogenicity. In the current study, animals treated with FB showed a significant decrease in RBCs, Hb, platelets and WBCs. The decrease in haemoglobin concentration and total RBCs resulting in normocytic normochromic anaemia. This decrease in the haemopoietic parameters may be due to many factors, such as inhibition of protein synthesis as indicated by lower body weight gain (Kaneko, 1989 and AbdelWahhab et al., 2002). Previous reports indicated that FB decreases the total iron binding capacity (Abdel-Wahhab et al., 2002, 2004) and affects the metabolism of minerals such as $\mathrm{Cu}$ and $\mathrm{Zn}$ (Abdel-Wahhab et al., 2002 and Tardieu et al., 2008). These results support our findings that FB cause normocytic normochromic anaemia. Moreover, the increase in the WBC count suggested that the toxin is eliciting an inflammatory response, and in turn causes alterations in bone marrow and the function of the immune system (Tryphonas $\boldsymbol{e t}$ al., 1997 and Mexía-Salazar et al., 2008).

The elevation in ALT, AST, ALP, triglycerides, cholesterol, uric acid, urea, createnine and CK levels and increased LDH in this group indicated necrosis or hepatocellular injury (AbdelWahhab et al., 2002 and El-Nekeety et al., 2007). FB administration enhanced the generation of free radicals which directly results of free radical-mediated toxicity (Norred and Voss, 1994 and Abdel-Wahhab et al., 2004 and El-Nekeety et al., 2007). The generation of free radicals is one of the main manifestations of oxidative damage and has been found to play an important role in the toxicity and carcinogenesis of many carcinogens. In this concern, AbdelWahhab and Ahmed (2004) reported that liver damage is directly related to free radical mediated toxicity. Free radicals are known to attack the highly unsaturated fatty acids of the cell membrane which considered a key process in many pathological events and is one of the reactions induced by oxidative stress (Schinella et al., 2002). Another mechanism of FB-induced injury was suggested by Pinelli et al. (1999) who stated that FB induced a down-regulation of cytoplasmic phospholipase A2 (cPLA2) activity and arachidonic acid (AA) metabolism by a mechanism involving prostaglandin production, cAMP synthesis and protein kinase (PKA) activation. Moreover, Seegers et al. (2000) stated that FB has inhibitor effects on ceramide synthesis, AA, prostaglandin $\mathrm{E}_{2}\left(\mathrm{PGE}_{2}\right)$ and prostaglandin A2 (PGA2). These authors suggested that FB decreased the lipid-enhanced tyrosine kinase activity, and in combination with AA, PGE2 or PGA2, FB increased the number of G2/M cells and decreased PGA2- and AAinduced p53 levels. Meli et al. (2000) indicated that cellular targets of FB include immune cells 
and in particular macrophages and it increased the production of prostaglandin E2 in rats.

The histological findings of the liver confirmed well the biochemical results. It is clearly noticed that the extract has a protective role against FBinduced liver damage as indicated by the improvement of the histological structure, DNA and protein content in the liver tissues. Similar histological changes in the liver tissues were reported by Abdel-Wahhab et al. (2002) and El-Nekeety et al. (2007). Moreover, Voss et al. (1996) and Abdel-Wahhab et al. (2004) stated that FB specifically disrupt cellular sphingolipid metabolism causing, among other things, increased levels of the sphinogoid base sphinganine and an increased sphinganine/sphingosine ratio. Such disruption was associated with a diversity of animal diseases. These include liver and kidney in rats (Abdel-Wahhab et al., 2002), liver and brain lesions in horses (Wang et al., 1992), liver and lung lesions in pigs (Riley et al., 1993) and liver lesions in chickens (Weibling et al., 1993b). FB was reported to induce liver lesions in rats which consist one or more of the following features: single cell necrosis, hepatocellular cytoplasmic vacuolation, variation in nuclear size and staining properties, pyknosis, fibrosis and bile duct proliferation, mild to marked hepatocellular hyperplasia, mitotic figures and foci of cellular alteration were found in the more severely affected livers(Norred and Voss, 1994; AbdelWahhab et al., 2002 and El-Nekeety et al., 2007).

According to Kampf et al. (1986), jojoba contains a natural antioxidant postulated to be an allylic derivative of hydroxytoluene. It is also contains $20-32 \%$ of protein, consisting mainly of albumins and globulins (Shrestha et al., 2002). Furthermore, Van Boven et al. (2000) stated that jojoba contains a group of glucosides, known as simmondsins and eight glucoside compounds have been isolated and identified form jojoba seeds (Bouali et al., 2008). The protective effects of the extract against FB-induced hematological, biochemical, histological and histochemical changes reported herein may be due to the free radicals scavenger properties of the extract (Abdel-Wahhab and Aly, 2003).
Another mechanism by which the extract may induce its protective effect through the enhancement of the synthesis of antioxidant enzymes in the liver (Yener et al., 2009).

The antioxidant activity of glucoside was reported by Mehta et al. (2009). Moreover, Abdel-Wahhab et al. (2007) concluded that simmondsin and simmondsin derivatives of glucoside decreased DNA damage and hepatocarcinogenesis induced by aflatoxin $\mathrm{B}_{1}$ by activating the phase II enzymes glutathione $S$ transferase (GST) and GSH peroxidase (GSH$\mathrm{PX})$. These results suggest that glucoside is capable of counteracting FB toxicity by suppressing cytochromes P-450 mediated bioactivation of FB. Jojobenoic acid constitute jojoba extract has antioxidant activity and has the ability to bind metal ions represents an additional means of modulating their pharmacological responses (Bouali et al, 2008). More importantly, jojoba extract itself was not toxic and did not exert any significant changes in the hematological and biochemical parameters tested or the histological structure of the liver. In this regards, previous reports showed that jojoba extract did not show any toxic manifestation on the general body metabolism and the blood serum parameters were within the normal range (Yaron, 1987 and Habashy et al., 2005).

It could be concluded that the ethanolic extract of jojoba has antioxidant effects and can protect against fumonisin-induced hepatotoxicity. This action may be due to its content of several antioxidant compounds that have the ability to scavenge free radicals generated by fumonisin and consequently prevent lipid peroxidation and/or the enhancement of the antioxidant enzymes in the cell.

\section{REFERENCES}

1- Abado-Becognee K, Mobio TA, Ennamany R, Fleurat-Lessard F, Shier WT, Badria $F$ and Creppy EE (1998): Cytotoxicity of fumonisin B1: implication of lipid peroxidation and inhibition of protein and DNA syntheses. Arch. Toxicol., 72: 233236.

2- Abdel-Wahhab MA and Ahmed HH (2004): Protective effects of Korean panax ginseng against chromium VI toxicity and free radical generation in 
rats. J. Ginseng Res., 28 (1): 11-17.

3- Abdel-Wahhab MA and Aly SE (2003): Antioxidants and radical scavenging properties of garlic, cabbage and onion in rats fed aflatoxincontaminated diet. J. Agric. Food Chem., 51: 24092414.

4- Abdel-Wahhab MA, Abdel-Galil MM, Hassan AM, Hassan NH, Nada SA, Saeed A and El-Sayed MM (2007): Zizyphus spina-christi extract protects against aflatoxin $\mathrm{B}_{1}$-intitiated hepatic carcinogenicity Afr. J. Trad. CAM, 4 (3): 248-256.

5- Abdel-Wahhab MA, Amer HA, Hassan NS, Hassan AM and Naguib KhM (2002): Effects of garlic and cabbage extracts on fuminisin-induced toxicity in rats. J. Egypt. Soc. Toxicol., 26: 1-12.

6- Abdel-Wahhab MA, Hassan AM, Amer HA and Naguib KhM (2004): Prevention of fumonisininduced maternal and developmental toxicity in rats by certain plant extracts. J. Appl. Toxicol., 24: 469474.

7- Abel S and Gelderblom WC (1998): Oxidative damage and fumonisin $\mathrm{B}_{1}$-induced toxicity in primary rat hepatocytes and rat liver in vivo. Toxicology, 131(2-3): 121-131.

8- Bancrofte JD and Stevens A (1990): Theory and Practice of Histological Technique. $3^{\text {rd }}$ edition, Churchill livingstone, Edinburgh, London, and New York, pp: 148.

9- Bezuidenhout SC, Gelderblom WCA, GorstAllman CP, Horak RM, Marasas WFO, Spiteller G and Vleggaar, $R$ (1988): Structure elucidation of the fumonisins, mycotoxins from Fusarium moniliforme. J. Chem. Soc. Chem. Commun., 11: 743-745.

10- Borlaug N, Baldwin AR, Estefan R, Harris $M$ and Plucknett DL (1985): Jojoba: new crop for arid lands. New raw material for industry. Washington, DC: National Academy Press; p. 6, 13.

11- Bouali A, Bellirou A, Boukhatem N, Hamal A and Bouammali, B (2008): Enzymatic detoxification of jojoba meal and effect of the resulying meal on food intake in rats. Nat Prod Res., 22(7): 638-647.

12- Brown TP, Rottinghaus GE and Williams, ME (1992): Fumonisin mycotoxicosis in broilers: performance and pathology. Avian Dis., 36: 450 454.

13- Cokelaere M, Flo G, Daenens P, Decuypere E, van Boven $M$ and Vermaut $S$ (1996): Food intake inhibitory activity of simmondsin and defatted jojoba meal: dose-response curves in rats. In: Janick, J. (Ed.), Progress in New Crops. ASHS Press, Arlington, VA, pp. 377-382.

14- Davidson S (1983): Jojoba: cautious optimisim. Rural Res 119: 21-25.

15- Drury RA, Wallington EA and Cancerson $R$ (1976): Carlton's Histopathological Techniques, fourth ed. Oxford University Press, Oxford. London, New York.

16- El-Nekeety AA, El-Kholy W, Abbas NF, Ebaid A, Amra HA and Abdel-Wahhab, MA (2007):
Efficacy of royal jelly against the oxidative stress of fumonisin in rats. Toxicon, 50: 256-269.

17- Gelderblom WC, Kriek NP, Marasas WF and Thiel PG (1991): Toxicity and carcinogenicity of the Fusarium moniliforme metabolite, fumonisin $\mathrm{B}_{1}$, in rats. Carcinogenesis, 12: 1247-1251.

18- Habashy RR, Abdel-Naim AB, Khalifa AE, AlAzizi MM (2005): Anti-inflammatory effects of jojoba liquid wax in experimental models. Pharmacol Res., 51(2): 95-105.

19- Haschek WM, Motelin G, Ness DK, Harlin KS, Hall WF, Vesonder RF, Peterson RF and Beasley VR (1992): Characterization of fumonisin toxicity in orally and intervenously dosed swine. Mycopathologia, 117: 83-88.

20- He, Q, Suzuki H, Sharma $\mathbf{N}$ and Sharma, RP (2006): Ceramide synthase inhibition by fumonisin $\mathrm{B}_{1}$ treatment activates sphingolipid-metabolizing systems in mouse liver. Toxicol. Sci., 94(2): 388397.

21- Hogan L (1978): Jojoba: new crop for arid regions of the world? Crops Soils Mag 31(2), 18-19.

22- Kampf A, Gringberg S, Galuun A (1986): Oxidative stability of jojoba wax. J Am Oil Chem Soc, 63: 246-248.

23- Kaneko JJ (1989): Clinical Chemistry of Domestic Animals ( $4^{\text {th }}$ ed) Academic Press: San Diego, CA.

24- Kim DH, Yoo HS, Lee YM, Kie JH, Jang S and Oh S (2006): Elevation of sphinganine 1-phosphate as a predictive biomarker for fumonisin exposure and toxicity in mice. J. Toxicol. Environ. Health A. 69 (23): 2071-2082.

25- Laurent D, Platzer N, Koh F, Sauviat MP and Pellegrin F (1989): Macrofusin and micromonilin: two new mycotoxins isolated from corn infested by Fusarium moniliforme Sheld. Microbiol. Aliments Nutr., 7: 9-16.

26- Mazia D, Brewer PA and Alfert M (1953): The cytochemical staining and measurement of protein with mercuric bromophenol blue. Biol. Bull., 104: 57-67.

27- Mehta BK, Pandit V and Gupta M (2009): New principles from seeds of Nigella sativa. Nat Prod Res., 23(2): 138-148.

28- Meli R, Ferrante MC, Raso GM, Cavaliere M, Di Carlo $R$ and Lucisano, $A$ (2000): Effect of fumonisin $\mathrm{B}_{1}$ on inducible nitric oxide synthase and cyclooxygenase-2 in LPS-stimulated J774A.1 cells. Life Sci., 67(23): 2845-2853.

29- Mexía-Salazar AL, Hernández-López J, BurgosHernández A, Cortez-Rocha MO, CastroLongoria R and Ezquerra-Brauer JM (2008): Role of fumonisin $B_{1}$ on the immune system, histopathology, and muscle proteins of white shrimp (Litopenaeus vannamei). Food Chem., 110 (2): 471479.

30- Mobio TA, Anane R, Baudrimont I, Carratu MR, Shier TW, Dano SD, Ueno $Y$ and Creppy EE (2000): Epigenetic properties of fumonisin $B_{1}$ : cell cycle arrest and DNA base modificaion in C6 glioma 
cells. Toxicol. Appl. Pharmacol., 164: 91-96.

31- Norred WP and Voss KA (1994): Toxicity and role of fumonisins in animal and human esophagal cancer. J. Food Prot., 57: 522-527.

32- Pinelli E, Poux N, Garren L, Pipy B, Castegnaro M, Miller DJ and Pfohl-Leszkowicz, A (1999): Activation of mitogen-activated protein kinase by fumonisin $\mathrm{B}_{1}$ stimulates $\mathrm{CPLA}(2)$ phosphorylation, the arachidonic acid cascade and cAMP production. Carcinogenesis, 20(9): 1683-1688.

33- Pohland AE (1996): Occurrence of fumonisins in the US food supply. Advances in Exp. Med. Biol., 392: 19-26.

34- Qureshi MA and Hagler WMJr (1992): Effect of fumonisin $\mathrm{B}_{1}$ exposure on chicken macrophage functions in vitro. Poult. Sci., 71: 104-112.

35- Riley RT and Voss KA (2006): Differential sensitivity of rat kidney and liver to fumonisin toxicity: organ-specific differences in toxin accumulation and sphingoid base metabolism. Toxicol. Sci., 92: 335-345.

36- Riley RT, Showker JL, Joo HS, Norred WP, Chamberlain WJ and Haschek NM (1993): Alteration of tissue and serum sphingonine to sphingosin ratio: an early biomarker in pigs of exposure to fumonisin containing feeds. Toxicol. Appl. Pharmacol., 118: 105-112.

37- Ross PF, Ledet AE, Owens DL, Rice LG, Nelson HA, Osweiler GD and Wilson TM (1993): Experimental equine leukoencephalomalacia, toxic hepatosis, and encephalopathy caused by corn naturally contaminated with fumonisins. J. Vet. Diagn. Invest., 5: 69-74.

38- SAS (1982): SAS User's Guide: Statistics. SAS Institute, Cary, N.C.

39- Schinella GR, Tournier HA, Prieto JM, Mordujovich de Buschiazzo P and Rios JL (2002): Antioxidant activity of anti-inflammatory plant extracts. Life Sci., 70: 1023-1033.

40- Seegers JC, Joubert AM, Panzer A, Lottering ML, Jordan CA, Joubert F, Maree JL, Bianchi P, de Kock $M$ and Gelderblom WC (2000): Fumonisin $\mathrm{B}_{1}$ influenced the effects of arachidonic acid, prostaglandins E2 and A2 on cell cycle progression, apoptosis induction, tyrosine- and CDC2- kinase activity in oesophageal cancer cells. Prostaglandins Leukot Essent Fatty Acids, 62(2): 75-84.

41- Shephard GS, Sydenham EW, Thiel PG and Gelderblom WCA (1990): Quantitative determination of fumonisins $\mathrm{B}_{1}$ and $\mathrm{B}_{2}$ by high performance liquid chromatography with fluorescence detection. J. Liq. Chromatogr., 13: 2077-2087.

42- Shephard GS, Thiel PG, Stockenstrom S and Sydenham EW (1996): Worldwide survey of fumonisin contamination of corn and corn-based products. J. AOAC Inter., 79: 671-687.

43- Shrestha MK, Peri I, Smirnoff P, Birk $Y$ and Golan-Goldhirsh A (2002): Jojoba seed meal proteins associated with proteolytic and protease inhibitory activities. J Agric Food Chem., 50(20): 5670-5675.

44- Stockmann-Juvala H, Mikkola J, Naarala J, Loikkanen J, Elovaara $E$ and Savolainen $K$ (2004): Oxidative stress induced by fumonisin $B_{1}$ in continuous human and rodent neural cell cultures. Free Radic. Res., 38 (9): 933-942.

45- Tardieu D, Bailly J, Skiba F, Grosjean F and Guerre $P$ (2008): Toxicokinetics of fumonisin $B_{1}$ in turkey poults and tissue persistence after exposure to a diet containing the maximum European tolerance for fumonisins in avian feeds. Food Chem. Toxico., 46 (9): 3213-3218.

46- Tessari EN, Oliveira CA, Cardoso AL, Ledoux DR and Rottinghaus GE (2006): Effects of Aflatoxin $B_{1}$ and fumonisin $\mathrm{B}_{1}$ on body weight, antibody titres and histology of broiler chicks. Br. Poult. Sci., 47 (3): 357-364.

47- Tran ST, Auvergne A, Bernard G, Bailly JD, Tradieu D, Babile $R$ and Guerre $P$ (2005): Chronic effects fumonisin $\mathrm{B}_{1}$ on ducks. Poult. Sci., 84: 22-28.

48- Tryphonas H, Bondy G, Miller JD, Lacroix F, Hodgen M, Mcguire $\mathbf{P}$, Fernie S, Miller D andHayward $S$ (1997): Effects of Fumonisin $B_{1}$ on the Immune System of Sprague-Dawley Rats Following a 14-Day Oral (Gavage) Exposure. Fund. Appl Toxicol., 39(1): 53-59.

49- Van Boven M, Holser R, Cokelaere M, Flo G and Decuypere E (2000): Gas chromatographic analysis of simmondsins and simmondsin ferulates in jojoba meal. J Agric Food Chem., 48(9): 4083-4086.

50- Visconti A, Boenke A, Doko MB, Solfrizzo $M$ and Pascale M (1991): Occurrence of fumonisin in Europe and the BCR-measurement and testing projects. Nat. Toxins, 3: 269-274.

51- Voss KA, Bacon CW, Meredith FI and Norred WP (1996): Comparative subchronic toxicity studies of Nixtamalized and water-extracted Fusarium moniliforme culture material. Food Chem.Toxicol.,34:623-632.

52- Voss KA, Howard PC, Riley RT, Sharma RP, Bucci TJ and Lorentzen RJ (2002): Carcinogenicity and mechanism of action of fumonisin $\mathrm{B}_{1}$ : A mycotoxin produced by Fusarium moniliforme $(=F$. verticillioides $)$. Cancer Detection and Prevention, 26: 1-9.

53- Voss, KA, Chamberlain, WJ, Bacon, CW, Norred, WP (1993): A preliminary investigation on renal and hepatic toxicity in rats fed purified fumonisin $\mathrm{B}_{1}$. Nat. Toxins 1, 222-228.

54- Waller RA and Duncan DB (1969): A Bayes rule for the symmetric multiple comparison problems. J. Am. Stat. Assoc., 64: 1484-1503.

55- Wang E, Norred WP, Bacon CW, Riley RT and Merrill AHJr (1991): Inhibition of sphingolipid biosynthesis by fumonisins: Implications for diseases associated with Fusarium moniliforme. J. Biol. Chem., 266: 14486-14490

56- Wang E, Ross PF, Wilson TM, Riley RT andMerrill Jr, AH (1992): Alteration of 
serumsphingolipids upon dietary exposure of ponies to fumonisins, mycotoxins produced by Fusarium moniliforme. J. Nutr., 122: 1706-1716.

57- Weibling TS, Ledoux DR, Bermudez AJ, Turk JR, Merrill Jr, AH (1993b): Effects of feeding Fusarium moniliforme culture material containing known levels of fumonisin $\mathrm{B}_{1}$ on the young broiler chick. Poult. Sci., 72: 266-456.

58- Weibling TS, Ledoux DR, Brown TP and Rottinghaus GE (1993a): Fumonisin toxicity in Turkey Poults. J. Vet. Diagn. Invest., 5: 75-78.
59- Yaron A (1987): Metabolism and effects of jojoba oil. In: Wisniak chemistry and technology of Champaign, IL: American Oil Press, p. 251-65.

60- Yener Z, Celik I, Ilhan $F$ and Bal $R$ (2009): Effects of Urtica dioica L. seed on lipid peroxidation, antioxidants and liver pathology in aflatoxin-induced tissue injury in rats. Food Chem Toxicol., 47(2): 418424. 


\section{تقييم التأثير الوقائي لمستخلص الجوجوبا ضد التسمم بالفيومانزين في الجرذان إنين}

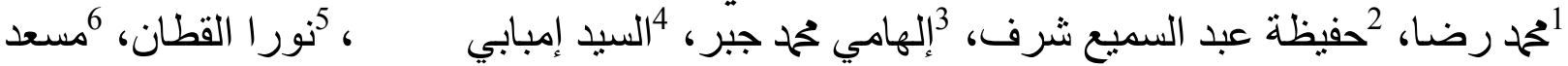
عطية عبد الوهاب

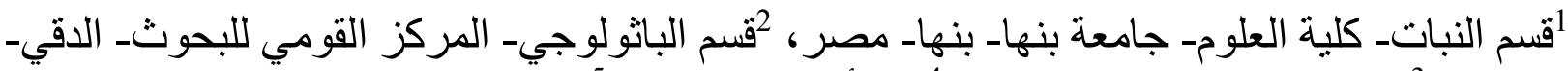

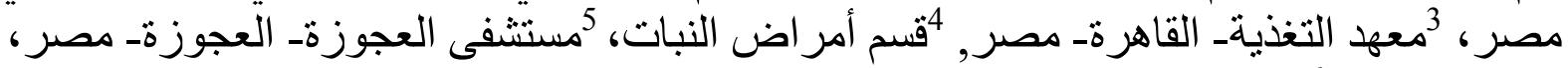

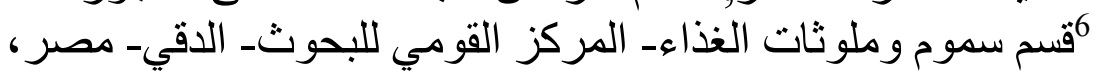

أجريت هذه الدراسة لتقييم التأثير الوقائي لمستخلص نبات الجوجوبا ضد التسمح بالفيومانزين في الجرذان حيث

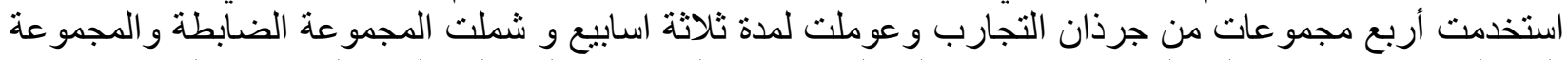

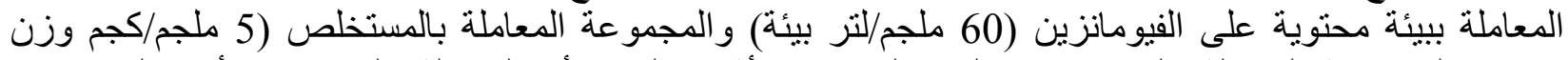

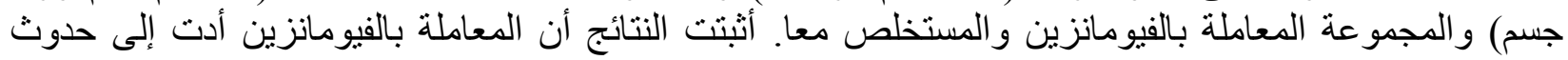

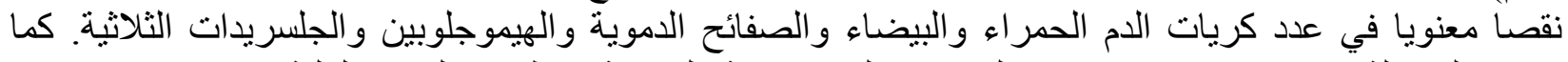

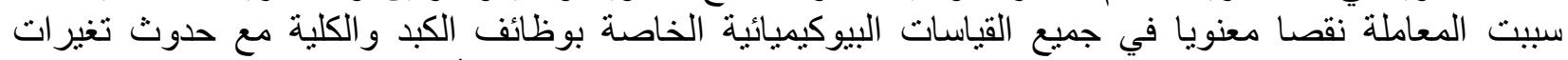

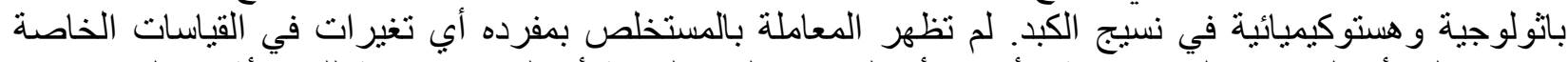

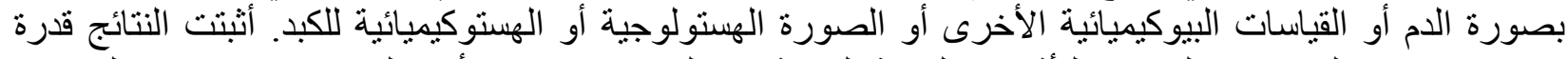

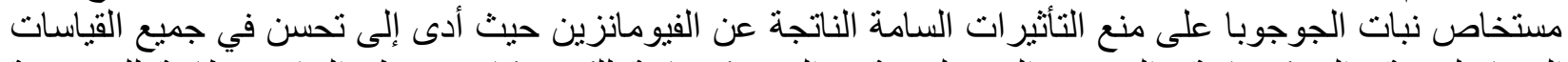

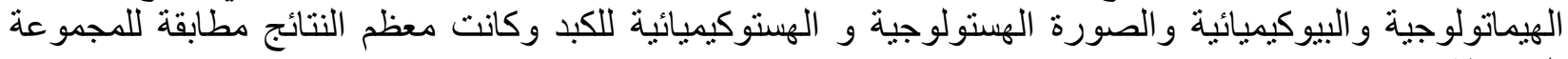

